\title{
The Role of Board of Commissioners in Islamic Social Reporting
}

\author{
Luluk Muhimatul Ifada ${ }^{1^{*}}$, Chrisna Suhendi ${ }^{2}$, Rustam Hanafi $^{3}$ \\ ${ }^{1,2,3}$ Department of Accounting, Faculty of Economics, Universitas Islam Sultan Agung, Indonesia \\ luluk.ifada@unissula.ac.id, chrisnasuhendi@unissula.ac.id,rustam@unissula.ac.id \\ *corresponding author
}

\begin{abstract}
This research aims to investigate how the board of commissioners plays a role in influencing Islamic social reporting. The object of this study was the disclosure of Islamic social reporting in sharia banking in Indonesia, through secondary data. Data were analyzed using multiple linear regression analysis. The findings showed the role of the board of commissioners in influencing the extent of Islamic social reporting disclosure more likely through the size of the board of commissioners, not through an independent board of commissioners or the number of board meetings. Researchers found that challenge of a great opportunity for the board of commissioners to contribute to social responsibility of companies in accordance with the provisions of Islam.
\end{abstract}

Keywords: Islamic social reporting, board of commissioners, sharia banks

\section{Peran Dewan Komisaris dalam Islamic Social Reporting}

\begin{abstract}
Abstrak
Penelitian ini bertujuan untuk mengetahui peran dewan komisaris dalam mempengaruhi Islamic social reporting. Objek penelitian ini adalah pengungkapan Islamic social reporting pada perbankan syariah di Indonesia, melalui data sekunder. Analisis data menggunakan analisis regresi linier berganda. Temuan menunjukkan bahwa peran dewan komisaris dalam mempengaruhi pengungkapan Islamic social reporting cenderung melalui ukuran dewan komisaris, bukan melalui dewan komisaris independen atau jumlah rapat dewan. Peneliti menemukan bahwa terdapat tantangan yang menjadi peluang besar bagi dewan komisaris untuk berkontribusi pada tanggung jawab sosial perusahaan sesuai dengan ketentuan Islam.
\end{abstract}

Kata kunci: Islamic social reporting, board of commissioners, bank syariah

\section{INTRODUCTION}

The Indonesian economy like all economies throughout the world is in crisis. This is caused by the emergence of Covid-19 outbreak which has been declared a pandemic by the World Health Organization(WHO). After more than one year, the Covid-19 pandemic caused the decline in the stock price index and the rupiah exchange rate to the lowest figure in the last five years (2016-2020). To address this problem, Bank Indonesia has taken a number of measures to mitigate the effect of pandemic to maintain economic stability including strengthen the intensity of the triple invention policy to maintain the stability of the Rupiah exchange rate in accordance with market fundamentals and mechanisms (He, H., \& Harris, L., 2020). Moreover, the Indonesian government through the Ministry of Finance distributes Direct Cash Assistance to vulnerable communities affected by a pandemic crisis. The pandemic crisis is a challenge for various parties, including Sharia banking in Indonesia in reporting Islamic Social Reporting (ISR). This is in accordance with He and Harris (2020) that a pandemic can influence the fundamental development of Corporate Social Responsibility (CSR) and offer great opportunities for companies to carry out CSR. 
Islamic Social Responsibility (ISR) is a benchmark for the implementation of Sharia banking social responsibility that contains a compilation of CSR standard items set by the Accounting and Auditing Organization for Islamic Financial Institutions (AAOIFI). Mallin et al. (2014) shows that CSR in Sharia banks influences financial performance. Raimi et al. (2013) proved that Islamic organizations have been associated with CSR and reporting. To increase its ISR disclosure, Sharia Banks appoint a competent Board of Commissioners. This is because the commissioners have a competence, integrity and commitment to comply with the legislation.

The performance of board of commissioners is indicated by board size, board independence, and frequency of board meetings. Board size is the number of commissioners in a company (Khan, Muttakin, \& Siddiqui, 2013). The greater the size of the board of commissioners, the better the supervision will be. With good supervision, it is expected that Islamic social reporting will improve because it can minimize information that might be hidden by management. This is evidenced by research Indrawaty and Wardayati (2016) showing that that board size positively affects the ISR reporting, while research Lestari (2013) found that the board size has no effect on the ISR reporting. Board independence are commissioners who have no affiliation with the entity (Brick and Chidambaran, 2010).

The existence of an independent board of commissioners leads to a more comprehensive disclosure of ISR. This is because the independent board of commissioners functions to better oversee the company because it is more independent. Sunarsih and Ferdiansyah (2016) and Rahma and Bukair (2015) research results show that board independence has an effect on the disclosure of ISR. The frequency of board meetings is needed by the board of directors and shareholders (Gray and Nowland, 2013). The higher intensity of the board commissioner meeting is associated with a better coordination leading to increase ISR disclosure. This statement is in line with the research of Meutia and Febrianti (2017) showing that the more frequent board meeting can increase CSR disclosure in BUS .

This research discusses several potential directions on how the board of commissioners' decision making to address the pressing global social challenges. This study also aims to see how the board of commissioners plays a role in the pandemic crisis in influencing the ISR. CSR disclosure at Sharia banks is a form of corporate Responsibility for the community and the environment. Thus, the company will get the attention of the public that will make the company survive in the pandemic crisis. The results of this study can inform BUS to carry out social responsibility in accordance to the prescription of Islam.

\section{LITERATURE REVIEW}

\section{Board of Commissioner Size and Islamic Social Reporting}

The impact of Covid-19 on the global economy has been the worse since the Great Depression of the 1930s (Euronews, 2020). The impact of a pandemic crisis is indeed extraordinary in all aspects of life. Even when the Covid -19 pandemic ends, it is 
estimated that the impact of the pandemic crisis on the economic, social, political, and cultural aspects will continue for a long time. The challenge pandemic crisis is unquestionably offer great opportunities for board of commissioners to contribute to company to address these challenges by doing social responsibility in accordance with the provisions of I slam in economic downturn. This is useful to be used as consideration for ISR of Sharia banks. The board of commissioners is a very important element in the corporate governance mechanism. The existence of the board of commissioners is expected to be able to establish good management control system, especially in pandemic crisis to minimize hidden information by management. The greater the size of the board of commissioners, the more extensive the disclosure of corporate social responsibility will be. This supports the findings of studies conducted by Indrawaty and Wardayati (2016) that the size of the board of commissioners affects the disclosure of ISR.

\section{H1: The size of the board of commissioner positively affects the Islamic Social Reporting.}

\section{Independent board of commissioners and Islamic Social Reporting}

Current pandemic crisis also has a negative impact on cash flow and global liquidity demands, heterogeneity of the company's access to cash and credit all of which can affect the company's performance and market valuation (Harford, 1999; Kahle and Stulz, 2013; Pinkowitz et al., 2016; Giroud and Mueller, 2017). In overcoming the impact of the pandemic crisis, a special stimulus is needed in the company, namely by making the most of the functions of the independent board of commissioners. An independent board of commissioners is an entity within a company, usually consisting of an independent board of commissioners and comes from outside the company. In a crisis situation like the current pandemic, the independent board is instrumental in the company is to make a comprehensive assessment the performance of. According to Adams and Mehran (2005) with the existence of an independent board of commissioners, the interests of shareholders, both majority and minority are not ignored, because independent commissioners are more neutral towards decisions made by various parties. The existence of an independent board of commissioners on Sharia Banks in the current pandemic crisis can increase the protection of stakeholders and the process of preparing financial statements from the fraud that occurred during the current crisis pandemic. The existence of an independent board of commissioners can also cause companies to disclose more ISR of all company activities carried out in accordance with Islamic principles. This is because the independent board of commissioners supervises more independently so that the company is active in accordance with the established rules. This statement is in line with the findings of research by Sunarsih and Ferdiansyah (2016) and Rahma and Bukair (2015) that board independence has a positive influence on ISR disclosure.

H2: Independent board of commissioners has a positive effect on Islamic Social Reporting. 


\section{Number of Meetings of Board Commissioners and Islamic Social Reporting}

Companies can strengthen communication with stakeholders through social activities, such as creating safe and healthy workplaces, engaging in ethical business practices, providing sustainable and reliable services to customers, and investing in the environment and the local community in general. During the current pandemic crisis, social activities like this are really needed. Such social activities indicate the company has a commitment to show implicitly, which can increase the desire of stakeholders to support the company's operations, especially in difficult times like today (Deng et al., 2013). Furthermore, as pointed out by (Albuquerque et al., 2019), social activities can strengthen customer loyalty so as to reduce the company's vulnerability to economic decline. In this case, in order to satisfy the implicit contract between the company and stakeholders during this difficult pandemic crisis, of course the company needs regular meetings, one of which is the board of commissioners meeting to evaluate the policies of board of directors and its implementation. With a meeting, the board of commissioners can evaluate the policy of the board of directors. The higher frequency of the board of commissioners meets, there will be more monitoring of the implementation and disclosure of the ISR. The intensity of meetings of the board of commissioners increases ISR disclosure. This statement is consistent with the findings of research conducted by Meutia and Febrianti (2017) showing that the frequency and intensity of board of commissioners meetings has a positive effect on CSR disclosure at Sharia Banks.

H3: The number of board of commissioners' meetings has a positive effect on Islamic Social Reporting.

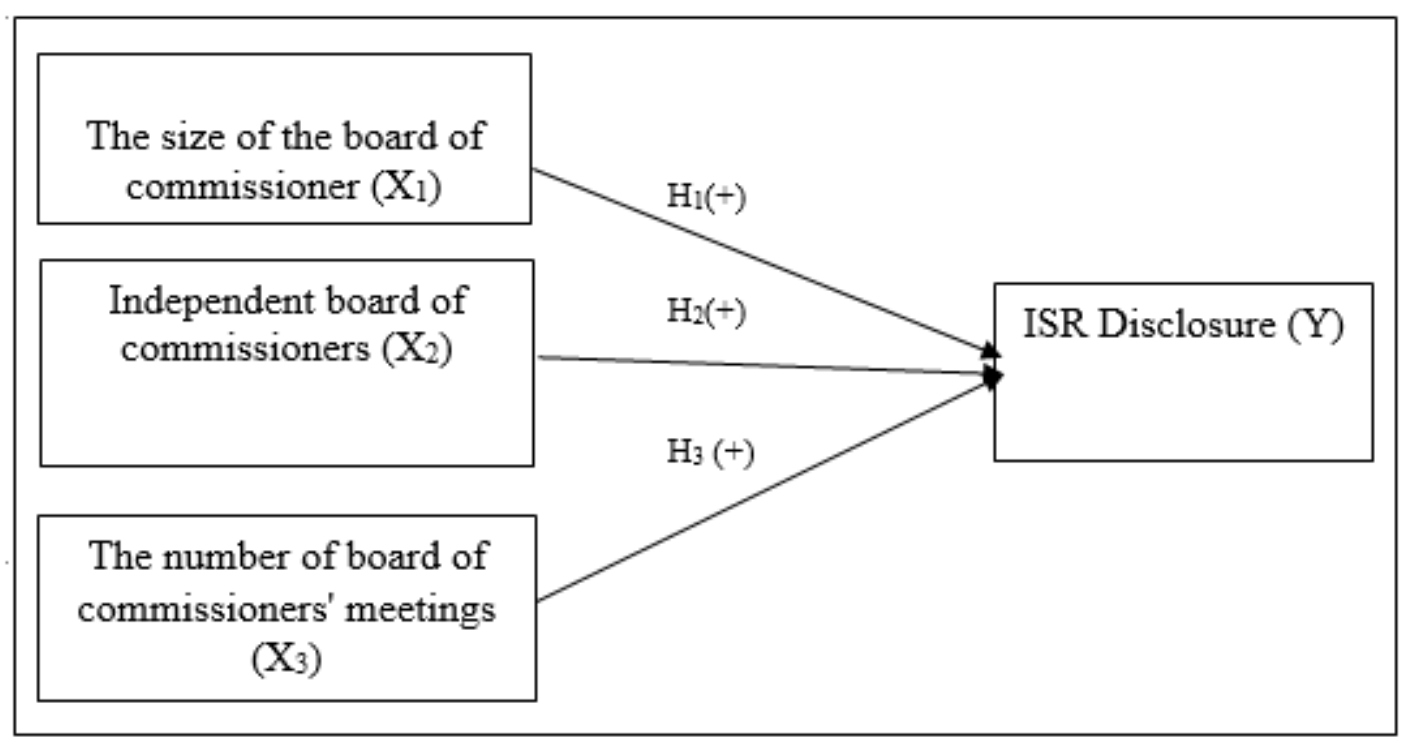

Figure 1. Research Model 


\section{METHOD}

The population in this study were all Sharia banks in Indonesia. Sampling was done by the census, the overall meaning of Sharia banks in Indonesia as many as 11 Sharia banks will be examined disclosure of Islamic social reporting it. The sample of Sharia banks in this study include: Muamalat Bank, Mega Indonesia Sharia Bank, BNI Sharia, BRI Sharia, Mandiri Sharia Bank, Maybank Sharia Indonesia, Victoria Sharia Bank, Panin Sharia Bank, Bukopin Sharia Bank, BPD West Java Banten Sharia, BCA Sharia. The number of samples in this study were 44 Sharia banks (11 Sharia Banks x 4 years) for the 2016-2019 period. To measure variables the following indicators were used:

\section{Islamic Social Reporting}

Islamic Social Reporting (ISR) is an extension of social reporting that is not only in the form of the desire of the entire community for the role of companies in the economy but is related to a spiritual perspective (Haniffa and Cooke, 2002). Islamic Social Reporting was measured using 38 social disclosure items.

Islamic Social Reporting $=\underline{\text { Number of disclosures }}$

Maximum score

The Islamic social reporting disclosure items are attached in appendix.

\section{Board Size}

Board size is the size that showed surveillance of information that may be hidden managers (Khan et al., 2013). The size of the board of commissioners can be seen from the number of commissioners in a company.

Board Size $=$ Number of Boards of Commissioners

\section{Independence Board}

According to Othman et al. (2009) Board of Commissioners is a corporate body responsible to supervise in general or specifically in accordance with the basic rules and also giving advice to directors as referred to in Law no 40 2017. The independent commissioner variable was calculated by summing the number of independent commissioners divided by the total members board of commissioners in a company (Lestari, 2013).

Board of Independence $=\quad$ Number of board independence

The number of the board of commissioners

\section{Frequency of Board Meetings}

The frequency of board of commissioners meetings is the number of meetings or internal meetings conducted by the Board of Commissioners within one year (Meutia and Febrianti, 2017). The frequency of board of commissioners' meetings is measured by 
calculating the number of meetings conducted by that the board of commissioners' in the company's annual report listed on the corporate governance report (Meutia and Febrianti, 2017).

Frequency of board meetings $=$ number of boards of commissioner's meetings

\section{Multiple Linear Regression for the analysis}

This study used statistical analysis techniques with multiple linear regressions. Previously, a descriptive statistical test and a classic assumption test were conducted. In addition, the researcher also conducted the normality test, the multicollinearity test and the heteroscedasticity test. The data were analyzed using SPSS software version 25, then the regression equation in this study is as follows:

$$
\mathrm{ISR}=\boldsymbol{\alpha}+\boldsymbol{\beta}_{1} \mathrm{X}_{1}+\boldsymbol{\beta}_{2} \mathrm{X}_{2}+\boldsymbol{\beta}_{3} \mathrm{X}_{3}+\varepsilon
$$

Information:

ISR : Islamic Social Reporting

$\alpha \quad$ : Constanta

$\beta_{1}, \beta_{2}, \beta_{3}$ : Regression Coefficient

$\mathrm{X}_{1} \quad$ : Board of Commissioners' size

$\mathrm{X}_{2} \quad$ : Independent Board of Commissioners

$\mathrm{X}_{3} \quad$ : Number of Board of Commissioners Meetings

$\varepsilon \quad:$ Error term

\section{FINDING AND DISCUSSION}

Table 1 shows descriptive statistical research variables

Table 1. Descriptive statistic

\begin{tabular}{lccccc}
\hline & N & Min & Max & The mean & Std. Deviation \\
\hline ISR & 44 &, 44 &, 81 &, 63 &, 111 \\
Board of Commissioners' size & 44 & 2 & 6 & 3.68 &, 959 \\
$\begin{array}{l}\text { Independent Board of } \\
\text { Commissioners }\end{array}$ & 44 & 14.00 & 100.00 & 64.17 & 21,922 \\
$\begin{array}{l}\text { Number of Board of } \\
\text { Commissioners Meetings }\end{array}$ & 44 & 2 & 49 & 18.80 & 10,418 \\
\hline
\end{tabular}

This study examined 11 Sharia Commercial Banks in Indonesia for 4 years so that the sample size was 44 Sharia Banks. From the table above it can be seen that the minimum value of the number of commissioners is 2 and the maximum value is 6 with an average of 3.68. The highest number of commissioners was found in PT. Bank Muamalat Indonesia with a board of commissioners consisting of 6 people for 2 years.

Based on POJK No. 33 / POJK.4 / 2014, the number of independent commissioners required to be owned is at least $30 \%$ (thirty percent) of the total members of the Board of Commissioners. Based on the table and diagram above, it can be seen 
that within a period of 4 years there are 4 (four) Sharia Banks that have independent commissioners of $0 \%-30 \%$, namely PT. Bank Sharia Bukopin in 2017, West Java BPD Banten Sharia in 2016 and 2017, and PT BCA Sharia in 2017.

Table 2. Summary of Independent Commissioners in the Company

\begin{tabular}{lcc}
\hline \multicolumn{1}{c}{ Information } & $\begin{array}{c}\text { Number of } \\
\text { Sharia Banks }\end{array}$ & $\begin{array}{c}\text { Sharia } \\
\text { Banks }\end{array}$ \\
\hline $\begin{array}{l}\text { Sharia Banks that have independent commissioners } 0 \%- \\
30 \%\end{array}$ & 4 & $9.09 \%$ \\
$\begin{array}{l}\text { Sharia Banks with independent commissioners } 31 \%- \\
40 \%\end{array}$ & 1 & $2.27 \%$ \\
Sharia Banks with independent commissioners 41\% - \\
$\begin{array}{l}50 \% \\
\text { Sharia Banks that have independent commissioners> } \\
50 \%\end{array}$
\end{tabular}

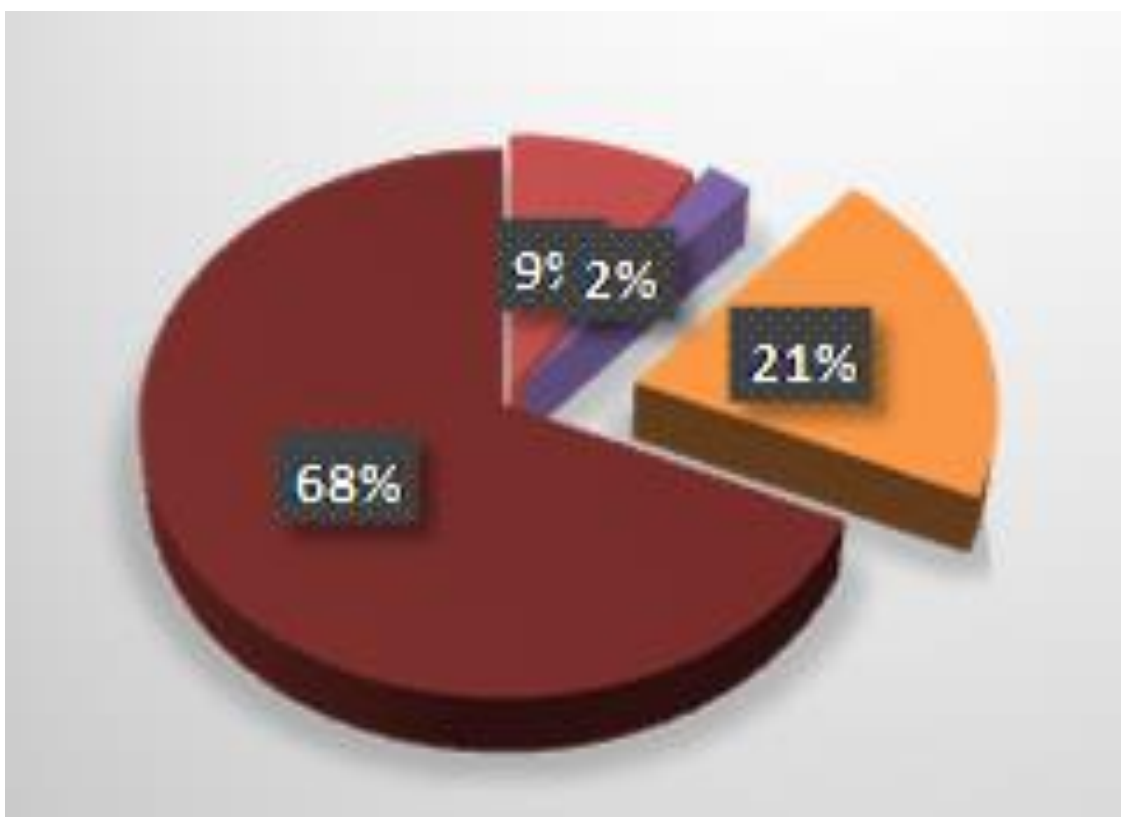

Figure 2. Independent Board of Commissioners

The number of meetings of the board of commissioners shows at least 2 times and at most 49 times in one year. The results of the descriptive statistical test also show a wide range of variable values with a standard deviation of 10.42 , more than half of the mean indicates that the data is widespread. There are still many who do not meet the Sharia Banks As a rule of thumbs Bank Indonesia No. 11/33 / PBI / 2009 wherein the Board of Commissioners Meeting must be held at least 1 (one) time in 2 months or at least in 1 (one) year is 6 times the Board of Commissioners Meeting. 
Table 3. Summary of Number of Board of Commissioners Meetings According to PBI No. 11/33 / PBI / 2009

\begin{tabular}{lcc}
\hline \multicolumn{1}{c}{ Information } & $\begin{array}{c}\text { Number of } \\
\text { Sharia Banks }\end{array}$ & Company \\
\hline $\begin{array}{l}\text { The number of board meetings }<6 \\
\text { times }\end{array}$ & 3 & $6.82 \%$ \\
$\begin{array}{l}\text { The number of board meetings }>6 \\
\text { times }\end{array}$ & 41 & $93.18 \%$ \\
Total & 44 & $100 \%$ \\
\hline
\end{tabular}

Table 4. Hypothesis Testing Results

\begin{tabular}{|c|c|c|c|c|c|c|}
\hline \multirow[t]{2}{*}{ Model } & \multicolumn{2}{|c|}{ Multicollinearity } & Heteroscedasticity & Unstandardized & $\mathbf{T}$ & Sig. \\
\hline & Tolerance & VIF & & B & & \\
\hline (Constant) & & & ,000 &, 610 & 6,330 & 000 \\
\hline $\begin{array}{l}\text { Board of } \\
\text { Commissioners' } \\
\text { size }\end{array}$ &, 620 & 1,614 & 0.963 &, 055 & 2,885 & 007 \\
\hline $\begin{array}{l}\text { Independent } \\
\text { Board of } \\
\text { Commissioners }\end{array}$ &, 628 & 1,592 & 0.697 &, 000 & $\begin{array}{c}- \\
441\end{array}$ & 662 \\
\hline $\begin{array}{l}\text { Number of } \\
\text { Board of } \\
\text { Commissioners } \\
\text { Meetings }\end{array}$ & , 400 & 2,501 & 0.534 &,- 002 & -976 & 335 \\
\hline
\end{tabular}

Dependent Variable: ISR

Asymp Sig (2-tailed) Kolmogorov-Smirnov, 577.

F test 3,324. P-value, 008. R Square, 393.

Adjusted R Square, 274. Durbin-Watson 1.443

Normality test results showed that that the table above values Asymp Sig (2tailed) at $0.577>0.05$ significance level that pertained normally distributed data. Multicollinearity test showed tolerance values above 0.10 and VIF values below 10 . This shows that this study did not occur in multicollinearity symptoms. While the autocorrelation test indicates the value of the Durbin-Watson was 1.443 located between $\mathrm{dL}<\mathrm{DW}<4-\mathrm{dU}=1.3749<1.443<2.3353$, so in this study did not happen autocorrelation. Heteroscedasticity test for all variables has a significant value that is $>$ 0.05 . It means, the regression model tested is free from heteroscedasticity. The value of the $\mathrm{F}$ test was 3.324 with a significance of 0.008 . This means that the significance value is less than 0.05. Thus, it can be concluded that the variable size of the board of commissioners, independent board of commissioners, and the number of board of commissioners' meetings together influence the ISR. Meanwhile, the value of R Square is 
$39.3 \%$ which means that the size of the board of commissioners, independent board of commissioners, and the number of boards of commissioner's meetings affects the ISR of $39.3 \%$ and the remaining $60.7 \%$ is influenced by other variables.

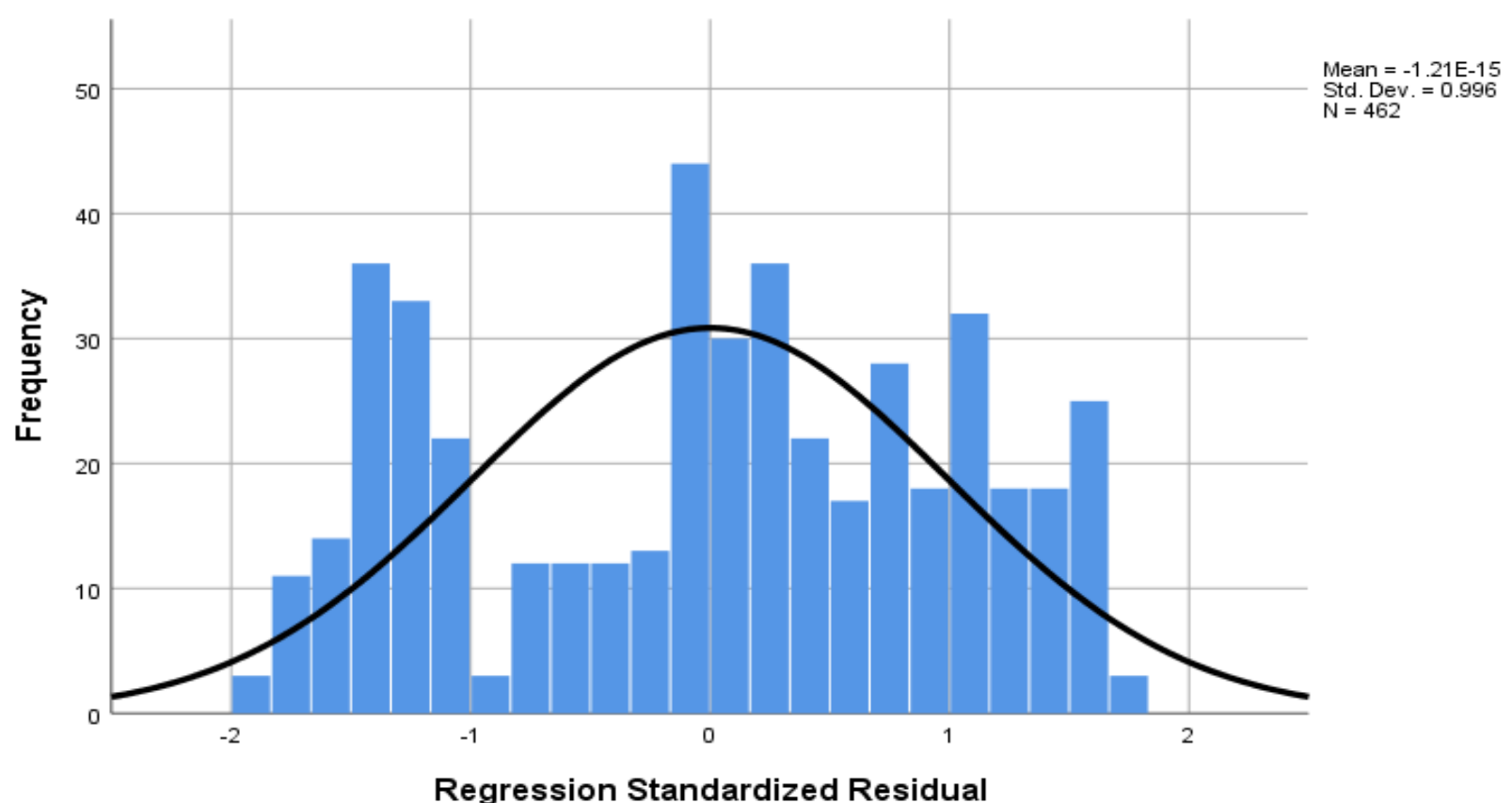

Figure 3. Normality Test with Histogram

Normality test in Figure 3 shows that the P-P data plot graph is normally distributed. It indicates that the data spread around the diagonal line and follow its line or the histogram graph.

\section{Board of Commissioners' Size and Islamic Social Reporting}

The results of this study obtained the results of the size of the board of commissioners had a significant positive effect on ISR with a significance value of 0.007 $<\alpha=0.05$. While the value on the coefficient $\beta$ size of the board of commissioners was positive at 0.055 . So, it can be concluded that the first hypothesis, namely the size of the board of commissioners had a significant positive effect on ISR during the pandemic crisis, was accepted.

In this study, the effect of the size of the board of commissioners on ISR during the crisis of the pandemic was that the board of commissioners contributed to the company in overcoming the challenges of a pandemic crisis by carrying out social responsibility in accordance with the provisions of I slam in the economic downturn. This is useful to be used as consideration for ISR of Sharia banking companies. The existence of the board of commissioners is expected to be able to encourage the creation of good management control, especially in the current crisis pandemic, so as to minimize information that might be hidden by management. The greater the size of the board of commissioners, the disclosure of corporate social responsibility will be more extensive. 
The results of previous studies that are aligned with the results of study by (Sulistyawati \& Yuliani, 2017)Indrawaty and Wardayati (2016), Haribowo (2016) who argued that there is an influence on the disclosure of CSR commissioners on Sharia bank in its annual report. However, this study contradicts Lestari (2013) study which argues that the size of the board of commissioners has no effect on ISR disclosure.

\section{Independent board of commissioners and Islamic Social Reporting}

The results of this study obtained the results of the independent board of commissioners had no effect on ISR during the pandemic crisis with a significance value of $0.662>\alpha=0.05$. So, it can be concluded that the second hypothesis that independent board has a significant positive effect on the ISR during a pandemic crisis is rejected. The Independent commissioners did not affect the ISR in the crisis of the pandemic because theoretically that lack of independence of commissioners caused ineffective roles and responsibilities undertaken then impact on the reporting of corporate responsibility. The existence of the independent board of commissioners in a company for the time being is highly expected to be a neutral and independent party in the face of every policy issued by directors According to Adams and Mehran (2005) with the existence of an independent board of commissioners, the interests of shareholders, both majority and minority are not ignored, because independent commissioners are more neutral towards decisions made by various parties. If independence is lost, then the supervisory function will also run poorly so as not to encourage the Sharia banks in expressing its social responsibility in accordance with the provisions of Islam in the condition of the economic downturn. The existence of an independent board of commissioners on Sharia banks is expected to be able to increase protection for stakeholders and the process of preparing financial statements will be avoided from fraud. However, the results of this study do not support this. The results of this study are in line with the results of research conducted by Sari (2014) which found that the independent board of commissioners had no effect on the ISR. However, this study contradicts the studies Sunarsih and Ferdiansyah (2016) and Rahma and Bukair (2015) that the independent board Air influence positively on the disclosure of ISR.

\section{Number of Meetings of Board Commissioners and Islamic Social Reporting}

The results of this study obtained the results of the board of commissioners meeting had no effect on ISR during the pandemic crisis with a significance value of $0,335>\alpha=0.05$. So, it can be concluded that the third hypothesis third that number of board meetings has a significant positive effect on the ISR during a pandemic crisis is rejected. In order to carry out their duties, the board of commissioners should hold regular meetings to evaluate the policies that must be taken by the board of directors and their implementation. However, if coordination at each board of commissioners meeting is lacking, it will cause a lack of policies in encouraging the creation of management control in the disclosure of ISR. So, Total board meetings does not affect the ISR. The results of this study are in line with research from (Brick and Chidambaran, 2010) who 
also found that the number of board of commissioners' meetings did not affect the level of CSR disclosure in Sharia banks. However, this study contradicts the study of Meutia and Febrianti (2017) that the frequency and intensity of the board of commissioners' meetings has a significant positive effect on CSR disclosure in Sharia Banks.

\section{CONCLUSION}

This present study leads to number of conclusions. The role of commissioners in the ISR represented by the size of Board of Commissioners affects positively on the ISR. The coefficient of determination (Adjusted R Square) is 0.274 it means that there is a contribution of $27.4 \%$ in predicting the ISR explained by the variable size of the board of commissioners. In this study, the greater the board of commissioners can recommend various policies or programs that can be given Sharia Banks.

In this study, certainly not free from limitations. A limitation that arises in this study is the small number of Sharia Banks in Indonesia. In addition, the secondary research setting does not allow Two-way communication between the researcher and Sharia Banks to obtain further information about the effect and the possible efforts. A further study using a combination of qualitative interviews to the Sharia Banks is needed.

\section{REFERENCES}

Adams, R. B., \& Mehran, H. (2005). Is Corporate Governance Different for Bank Holding Companies? SSRN Electronic Journal, (212). https://doi.org/10.2139/ssrn.387561

Albuquerque, R., Koskinen, Y., \& Zhang, C. (2019). Corporate social responsibility and firm risk: Theory and empirical evidence. Management Science, 65(10), 4451-4469. https://doi.org/10.1287/mnsc.2018.3043

Brick, I. E., \& Chidambaran, N. K. (2010). Board meetings, committee structure, and firm value. Journal of Corporate Finance, 16(4), 533-553. https://doi.org/10.1016/j.jcorpfin.2010.06.003

Charles, \& Chariri. (2012). Analisis Pengaruh Islamic Corporate Governance terhadap Corporate Social Responsibility (Studi Kasus Pada Bank Syariah di Indonesia). Diponegoro Journal of Accounting, 5(1), 1-15. https://doi.org/10.15408/ess.v5i1.2338

Deng, X., Kang, J. koo, \& Low, B. S. (2013). Corporate social responsibility and stakeholder value maximization: Evidence from mergers. Journal of Financial Economics, 110(1), 87-109. https://doi.org/10.1016/j.jfineco.2013.04.014

Erika. (2020). Ada dua tugas utama melawan pendemik covid-19, pencegahan dan tindakan solutif. Retrieved from https://republika.co.id/berita/q7xqm5282/keuangan-sosial-islam-melawan-dampakcovid19

Giroud, X., \& Mueller, H. M. (2017). Firm leverage, consumer demand, and employment 
Jurnal Economia, 17(2), October 2021, 195-207

losses during the great recession. Quarterly Journal of Economics, 132(1), 271-316. https://doi.org/10.1093/qje/qjw035

Gray, S., \& Nowland, J. (2013). Is prior director experience valuable? Accounting and Finance, 53(3), 643-666. https://doi.org/10.1111/j.1467-629X.2012.00481.x

Haniffa, R. M., \& Cooke, T. E. (2002). Culture, corporate governance and disclosure in Malaysian corporations. Abacus, 38(3), 317-349. https://doi.org/10.1111/1467$\underline{6281.00112}$

Harford, J. (1999). Corporate cash reserves and acquisitions. Journal of Finance, 54(6), 1969-1997. https://doi.org/10.1111/0022-1082.00179

He, H., \& Harris, L. (2020). The impact of Covid-19 pandemic on corporate social responsibility and marketing philosophy. Journal of Business Research, 116, 176-182. https://doi.org/10.1016/j.jbusres.2020.05.030

Indrawaty, \& Wardayati, S. M. (2016). Implementing Islamic Corporate Governance (ICG) and Islamic Social Reporting (ISR) in Islamic Financial Institution (IFI). Procedia - Social and Behavioral Sciences, 219, 338-343. https://doi.org/10.1016/j.sbspro.2016.04.042

Kahle, K. M., \& Stulz, R. M. (2013). Access to capital, investment, and the financial crisis. Journal of Financial Economics, 110(2), 280-299. https://doi.org/10.1016/j.jfineco.2013.02.014

Khan, A., Muttakin, M. B., \& Siddiqui, J. (2013). Corporate Governance and Corporate Social Responsibility Disclosures: Evidence from an Emerging Economy. Journal of Business Ethics, 114(2), 207-223. https://doi.org/10.1007/s10551-012-1336-0

Lestari, P. (2013). Determinants Of Islamic Social Reporting In Syariah Banks : Case Of Indonesia. International Journal of Business and Management Invention, 2(10), 28-34.

Mallin, C., Farag, H., \& Ow-Yong, K. (2014). Corporate social responsibility and financial performance in Islamic banks. Journal of Economic Behavior and Organization, 103. https://doi.org/10.1016/j.jebo.2014.03.001

Meutia, I., \& Febrianti, D. (2017). Islamic Social Reporting in Islamic Banking: Stakeholders Theory Perspective. SHS Web of Conferences, 34, 12001. https://doi.org/10.1051/shsconf/20173412001

Othman, R., Thani, A. M., \& Ghani, E. K. (2009). Determinants of Islamic Social Reporting Among Top Shariah -Approved Companies In Bursa Malaysia. Research Journal of International Studies, 12(12), 4-20. Retrieved from https://www.researchgate.net/publication/228783690\%0ADeterminants

Pinkowitz, L., Stulz, R. M., \& Williamson, R. (2016). Do U.S. firms hold more cash than foreign firms do? Review of Financial Studies, 29(2), 309-348. https://doi.org/10.1093/rfs/hhv064 
Rahma, A. A. n, \& Bukair, A. A. (2015). The Effect of the Board of Directors' Characteristics on Corporate Social Responsibility Disclosure by Islamic Banks. Journal of Management Research, 7(2), 506. https://doi.org/10.5296/jmr.v7i2.6989

Raimi, L., A., P., K., Y., \& A., A. (2013). Exploring the theological foundation of Corporate Social Responsibility in Islam, Christianity and Judaism for Strengthening Compliance and Reporting: An Eclectic Approach. Issues In Social And Environmental Accounting, 7(4), 228. https://doi.org/10.22164/isea.v7i4.112

Sulistyawati, A. I., \& Yuliani, I. (2017). Pengungkapan Islamic Reporting Pada Indeks Saham Syariah Indonesia. Jorunal Of Accounting \& Finance, 13(2), 15-27.

Sunarsih, U., \& Ferdiansyah, F. (2016). Determinants of The Islamic Social Reporting Disclosure. Al-Iqtishad: Journal of Islamic Economics, 9(1), 69-80. https://doi.org/10.15408/aiq.v9i1.3771 